\title{
Cold Acclimation Treatment-induced Changes in Abscisic Acid, Cytokinin, and Antioxidant Metabolism in Zoysiagrass (Zoysia japonica)
}

\author{
Lixin Xu and Mili Zhang \\ Turfgrass Research Institute, Beijing Forestry University, Beijing, China \\ 100083
}

\author{
Xunzhong Zhang ${ }^{1}$ \\ Department of Crop and Soil Environmental Sciences, Virginia Polytechnic \\ Institute and State University, Blacksburg, VA 24061
}

\author{
Lie-Bao Han ${ }^{1}$ \\ Turfgrass Research Institute, Beijing Forestry University, Beijing, China \\ 100083
}

Additional index words. antioxidant, cold, hormone, turfgrass, Zoysia japonica

\begin{abstract}
Zoysiagrass (Zoysia spp.), a warm-season turfgrass species, experiences freezing damage in many regions. The mechanisms of its cold acclimation and freezing tolerance have not been well understood. This study was designed to investigate effects of cold acclimation treatment on leaf abscisic acid (ABA), cytokinin (transzeatin riboside $(t-Z R)$, and antioxidant metabolism associated with freezing tolerance in zoysiagrass (Zoysia japonica). 'Chinese Common' zoysiagrass was subjected to either cold acclimation treatment with temperature at $8 / 2{ }^{\circ} \mathrm{C}$ (day/night) and a photosynthetically active radiation $(P A R)$ of $250 \mu \mathrm{mol} \cdot \mathrm{m}^{-2} \cdot \mathrm{s}^{-1}$ over a 10 -hour photoperiod or normal environments (temperature at $28 / 24{ }^{\circ} \mathrm{C}$ (day/night), $P A R$ at $400 \mu \mathrm{mol} \cdot \mathrm{m}^{-2} \cdot \mathrm{s}^{-1}$ and 14-hour photoperiod) for 21 days in growth chambers. Cold treatment caused cell membrane injury as indicated by increased leaf cell membrane electrolyte leakage (EL) and malondialdehyde (MDA) content after 7 days of cold treatment. Cold treatment increased leaf $\mathrm{ABA}$ and hydrogen peroxide content and reduced $t$-ZR content. Leaf superoxide dismutase (SOD), ascorbate peroxidase (APX) activity, and proline content increased, whereas catalase (CAT) and peroxidase (POD) activity declined in response to cold treatment. Cold treatment increased freezing tolerance as $\mathrm{LT}_{50}$ declined from -4.8 to $-12.5^{\circ} \mathrm{C}$. The results of this study indicated that cold acclimation treatment might result in increases in $\mathrm{ABA}$ and $\mathrm{H}_{2} \mathrm{O}_{2}$, which induce antioxidant metabolism responses and improved freezing tolerance in zoysiagrass.
\end{abstract}

Zoysiagrass (Zoysia spp.) is a common warm-season turfgrass well adapted in use of lawns and golf courses in many regions because of its excellent heat tolerance, density, low pesticide requirements, and minimal maintenance inputs (Patton et al., 2007a, 2007b; Zhang et al., 2009). Expanded use of zoysiagrass could play an important role in making golf courses and home lawns more environmentally friendly and sustainable (Patton and Reicher, 2007). However, the use of zoysiagrasses has been limited by its relatively weak winter hardiness compared with some other $\mathrm{C}_{4}$ turfgrass species, such as bafflograss, and freezing injury in many

\footnotetext{
Received for publication 30 Jan. 2015. Accepted for publication 30 Apr. 2015.

This research was supported by Forestry Bureau of China (948 project No. 2011-4-50) and National Science Foundation of China (No. 31172255).

${ }^{1}$ To whom reprints request should be addressed; e-mail xuzhang@vt.edu; hanliebao@163.com.
}

regions. Freezing temperature may cause damage by forming ice crystals, which result in rupture of cell membranes and cell dehydration (Fry and Huang, 2004; Zhang et al., 2008). Injury during exposure to chilling temperature also results from reduced or defective metabolic defense functions (Karpinski et al., 2002; Thomashow, 1999).

Zoysiagrasses undergo cold acclimation in late fall as temperature drop and photoperiod gets shorter. It has been well documented that increased cold acclimation could improve freeze tolerance of plants, including turfgrasses (Anderson et al., 2003). Plants possess various adaptive mechanisms for surviving freezing temperature such as increases in certain sugars or amino acids, increases in ABA content, and antioxidant capacity (Patton et al., 2007a, 2007b; Rogers et al., 1977; Zhang and Ervin, 2008; Zhang et al., 2009).

Various metabolites (such as proline) may accumulate during cold acclimation (Zhang and Ervin, 2008; Zhang et al., 2006, 2008). Proline, an amino acid, functions as osmoprotectant and antioxidant to protect cell membrane during dehydration. Patton et al. (2007a, 2007b) reported that proline content increased in response to cold acclimation in zoysiagrasses. Bermudagrass (Cynodon L.C. Rich) cultivars with higher stolon proline content exhibited greater freezing tolerance than those with lower proline during the winter (Munshaw et al., 2006).

Decreases in temperature and photoperiod in fall may create an imbalance, so that the energy absorbed through the light harvesting complex exceeds what can be dissipated or transduced by photosystem II (PSII; Karpinski et al., 2002; Zhang and Ervin, 2008). Excess energy may be directed to $\mathrm{O}_{2}$ and result in accumulation of toxic reactive oxygen species (ROS). To protect from oxidative stress, plants have developed efficient antioxidant defense systems to scavenge ROS such as superoxide radicals $\left(\mathrm{O}_{2}{ }^{-}\right)$, hydrogen peroxide $\left(\mathrm{H}_{2} \mathrm{O}_{2}\right)$, and hydroxyl radicals $\left(\mathrm{HO}^{-}\right)$(McKersie and Bowley, 1997). The SOD (EC 1.15.11), a group of metalloenzymes, can convert $\mathrm{O}_{2}^{-}$to $\mathrm{H}_{2} \mathrm{O}_{2}$, and considered as the "primary defense" against ROS (Perl-Treves and Perl, 2002; Zhang et al., 2008). The $\mathrm{H}_{2} \mathrm{O}_{2}$ is further reduced to water by the antioxidant enzymes-CAT (EC 1.11.1.6) and APX (EC 1.11.1.11). The CAT, localized in peroxisomes, scavenges $\mathrm{H}_{2} \mathrm{O}_{2}$ produced by glycolate oxidase in the $\mathrm{C}_{2}$ photorespiratory cycle (Perl-Treves and Perl, 2002). POD (EC 1.11.17) is also an important antioxidant enzyme for scavenging ROS. Antioxidant enzymes and metabolites have been shown to be associated with freezing tolerance in plants, including bermudagrass (Karpinski et al., 2002; Zhang and Ervin, 2008). Overexpression of a chloroplast $\mathrm{Cu} / \mathrm{Zn}$ SOD gene increased resistance to chilling stress in tobacco (Gupta et al., 1993).

ABA and $\mathrm{H}_{2} \mathrm{O}_{2}$ have been considered as signaling molecules for inducing plant antioxidant defense systems against abiotic stresses (Xiong et al., 2002). Cytokinins exhibit antisenescence and antioxidant function. Heino et al. (1990) reported that ABA deficiency prevented development of freezing tolerance in Arabidopsis thaliana. Stolon ABA accumulation during cold acclimation is associated with freezing tolerance in bermudagrass (Zhang et al., 2008) and zoysiagrass (Zhang et al., 2009), and exogenous ABA increased freezing tolerance of bermudagrass (Zhang et al., 2008). Hu et al. (2006) found that $\mathrm{ABA}$ is a key inducer of $\mathrm{H}_{2} \mathrm{O}_{2}$ production in maize exposed to drought stress. Hsu and Kao (2010) indicated that ABA-induced leaf senescence of rice seedlings is due to $\mathrm{H}_{2} \mathrm{O}_{2}$ accumulation. Prasad et al. (1994) reported that accumulation of ABA and $\mathrm{H}_{2} \mathrm{O}_{2}$ protect mitochondria against $\mathrm{CI}$ in maize seedlings.

Cytokinins are adenine derivatives characterized by an ability to induce cell division in tissue culture (in the presence of auxin). They also promote shoot initiation, lateral 
bud growth, leaf expansion, nutrient mobilization, chloroplast differentiation, and activation of shoot meristems and delay senescence (Davies, 2010). Zeatin and zeatin riboside are some of the most important forms of cytokinins. Cytokinins are synthesized in root tips and developing seeds and transported from roots to shoots via the xylem (Davies, 2010). Taylor et al. (1990) measured cytokinin and ABA levels in fieldand growth chamber-grown winter wheat plants. They found that ABA level increased, whereas cytokinin level declined during cold acclimation.

Research on changes of ABA, cytokinin, and $\mathrm{H}_{2} \mathrm{O}_{2}$ associated with antioxidant metabolism in zoysiagrass is lacking. Very few studies have been reported on antioxidant metabolism associated with cold acclimation and freezing tolerance in zoysiagrass. Investigations concerning the physiological responses of zoysiagrass to cold acclimation treatment would provide valuable selection information for turfgrass breeders and practitioners. The objectives of this study were to examine effect of cold acclimation treatment on the levels of ABA, cytokinin, and antioxidant enzyme activity and to investigate if cold treatment-induced changes of the hormones and antioxidants are associated with freezing tolerance in zoysiagrass.

\section{Materials and Methods}

Zoysiagrass culture and cold acclimation treatment. One zoysiagrass cultivar, Chinese common (relatively cold tolerant and widely used in China and some other regions), was used for this study (Patton and Reicher, 2007). Mature zoysiagrass plugs $(25 \mathrm{~cm}$ diameter by $5 \mathrm{~cm}$ deep) were taken from field plots at the Turfgrass Research Institute, Beijing Forestry University, Beijing, China. The grass was transplanted on 15 June 2012 and grown in the pots $(25.4 \mathrm{~cm}$ diameter $\times 24.1 \mathrm{~cm}$ deep $)$ filled with a mixture of top soil and sand (4:1, $\mathrm{w} / \mathrm{w})$ in a temperature-controlled greenhouse with temperature at $28 / 24{ }^{\circ} \mathrm{C}$ (day/night) and a $P A R$ at $400 \mu \mathrm{mol} \cdot \mathrm{m}^{-2} \cdot \mathrm{s}^{-1}$ with $\approx 14$-h photoperiod. The greenhouse was covered with a dark plastic sheet and artificial lamps (YZ28T5; NVC Lighting Technology Corporation, Huizhou, China) were used to achieve uniform light environment. Nitrogen was applied at $45 \mathrm{~kg} \cdot \mathrm{ha}^{-1}$ with a $20 \mathrm{~N}-8.8 \mathrm{P}-16.6 \mathrm{~K}$ soluble fertilizer $1 \mathrm{~d}$ after the plugs were transplanted and $23 \mathrm{~kg} \cdot \mathrm{ha}^{-1}$ every 4 weeks thereafter. The pots were irrigated by hand once every $3 \mathrm{~d}$ and trimmed at $4 \mathrm{~cm}$ height.

Two months after transplanting, each of five pots was placed in a growth chamber and subjected to cold acclimation at $8 / 2{ }^{\circ} \mathrm{C}$ (day/ night) with a $P A R$ of $250 \mu \mathrm{mol} \cdot \mathrm{m}^{-2} \cdot \mathrm{s}^{-1}$ over a 10-h photoperiod for a period of $21 \mathrm{~d}$ (Zhang et al., 2006, 2008), and each of the other five pots was placed in another growth chamber with temperature at $28 / 24{ }^{\circ} \mathrm{C}$ (day/night) and $P A R$ at $400 \mu \mathrm{mol} \cdot \mathrm{m}^{-2} \cdot \mathrm{s}^{-1}$ over a 14 -h photoperiod for a period of $21 \mathrm{~d}$ (Zhang et al., 2008). The two treatments (cold acclimation and non-acclimated) were replicated for five times and a total of 10 growth chambers were used for this study. The irrigation was provided only in need to make sure no moisture stress occurred. No fertilization was provided during $21 \mathrm{~d}$ of cold acclimation treatment. The experiment was repeated from July through Oct. 2013.

Sampling collection. Leaf samples were collected from each pot at $0,7,14$, and $21 \mathrm{~d}$ after cold acclimation treatment initiation. Leaf EL was measured immediately after sampling. Leaf samples were frozen with liquid nitrogen and stored at $-80{ }^{\circ} \mathrm{C}$ for analysis of $\mathrm{ABA}, \mathrm{ZR}$, proline, $\mathrm{MDA}, \mathrm{H}_{2} \mathrm{O}_{2}$, and antioxidant enzyme activity. In addition, stolons were sampled at 0 and $21 \mathrm{~d}$ and used for determination of $\mathrm{LT}_{50}$. Stolon tissue was used for $\mathrm{LT}_{50}$ measurement because it is closely related to the plant survival of freezing temperature (Zhang et al., 2006, 2008).

Leaf $E L$ and $L T_{50}$ determination. Leaf tissues $(50 \mathrm{mg})$ were collected and rinsed with deionized water, and then cut into small sections $(5 \mathrm{~mm})$. The samples were placed in $50-\mathrm{mL}$ tubes with $20 \mathrm{~mL}$ distilled water. The tubes were shaken for $24 \mathrm{~h}$ at $25{ }^{\circ} \mathrm{C}$ and an initial electrical conductance (EC1) was determined using a conductivity meter (Model DDSJ_308A; Shanghai Precision and Scientific Inc., Shanghai, China). The samples were autoclaved at $120{ }^{\circ} \mathrm{C}$ for $30 \mathrm{~min}$ and cooled down to $25{ }^{\circ} \mathrm{C}$ and final electrical conductance (EC2) was measured. The EL $(\%)$ is expressed as $(\mathrm{EC} 1 / \mathrm{EC} 2) \times 100$ (Blum and Ebercon, 1981).

The concept of lethal temperature for $50 \%$ loss of electrolytes $\left(\mathrm{LT}_{50}\right)$ has been used as a measure of cold hardiness and is defined as the predicted test temperature resulting in $50 \%$ or greater loss of total electrolytes (Zhang et al., 2008). At the beginning (0 d) and the end $(21 \mathrm{~d})$ of cold acclimation treatment, stolon $\mathrm{LT}_{50}$ was determined according to Zhang et al. (2008). Briefly, the soil was washed from the plants and the roots were removed. Turfgrass from each pot was then divided into five subsamples. Each subsample was wrapped in a wet paper towel and subjected to a series of freezing temperature. A freezing chamber was programmed to cool to $-3,-6,-9,-13$, and $-17^{\circ} \mathrm{C}$ with a $2{ }^{\circ} \mathrm{C}$ decline every $2 \mathrm{~h}$ at which time a subsample was removed for analysis. After thawing overnight at $4{ }^{\circ} \mathrm{C}$, stolons were collected and the EL was determined according to the procedure as described previously. Zoysiagrass freezing tolerance was evaluated based on predicted killing temperature from EL measurements in this study. The response curve between test temperature and EL was fitted to a sigmoidal response using Sigmaplot v.10 (Systat Software Inc., San Jose, CA). Response curves were developed for each treatment and each $\mathrm{LT}_{50}$ was determined from the inflection point of the curve (Tmid) based on the sigmoidal response equation.

Leaf MDA content. Lipid peroxidation of the leaf tissue was measured in terms of MDA content (Dhindsa and Matowe, 1981) with some modifications. Frozen leaf tissues $(50 \mathrm{mg})$ was ground to a powder with a mortar and a pestle in liquid nitrogen and extracted with $2 \mathrm{~mL} 10 \%$ trichloroacetic acid (TCA) on an ice bath. The mixture was centrifuged at $10,000 \mathrm{~g}_{\mathrm{n}}$ for $10 \mathrm{~min}$ at $4{ }^{\circ} \mathrm{C}$. Supernatant $(1.5 \mathrm{~mL})$ was collected and mixed with $2 \mathrm{~mL}$ $0.67 \%$ thiobarbituric acid (TBA). The mixture was heated at $95{ }^{\circ} \mathrm{C}$ for $15 \mathrm{~min}$ and cooled down in an ice bath. The mixture was centrifuged again at $10,000 \mathrm{~g}_{\mathrm{n}}$ for $10 \mathrm{~min}$ at $4{ }^{\circ} \mathrm{C}$. The absorbance of supernatant was determined at 450, 532, and $600 \mathrm{~nm}$. The formula for the calculation of MDA content was MDA content $\left(\mu \mathrm{mol} \cdot \mathrm{g}^{-1}\right.$ fresh weight $)=$ $\left[6.45\left(\mathrm{~A}_{532}-\mathrm{A}_{600}\right)-0.56 \mathrm{~A}_{450}\right] \times \mathrm{v} / \mathrm{w}$, where $\mathrm{v}$ is the volume of cuvette and $\mathrm{w}$ is the weight of leaf tissues in each sample.

Leaf $A B A$ and $t-Z R$ content. The ABA in leaf tissues was extracted and purified according to the procedure described by Man et al. (2011). Briefly, leaf tissue (400 mg) was ground with a mortar and a pestle in liquid nitrogen and homogenized in $5-\mathrm{mL}$ Na-phosphate buffer $(0.05 \mathrm{M}, \mathrm{pH} 7.0)$ containing $0.02 \%$ sodium diethyldithiocarbamate as an antioxidant and the hormones were extracted by continuous shaking for $2 \mathrm{~h}$ at $4{ }^{\circ} \mathrm{C}$. The samples were transferred into test tubes after extraction and $\mathrm{pH}$ was adjusted to 2.6 with $1.0 \mathrm{M} \mathrm{HCl}$. The sample was slurried with Amberlite XAD-7 (Sigma, St. Louis, MO) for $30 \mathrm{~min}$. After removal of the buffer, the XAD-7 was washed two times with $4 \mathrm{~mL}$ of $1 \%$ acetic acid before being slurried two times with $5 \mathrm{~mL}$ dichloromethane for $30 \mathrm{~min}$. The combined dichloromethane fractions were reduced to dryness with nitrogen gas. Then samples were dissolved in methanol $(30 \mu \mathrm{L})$ and diluted with $0.6 \mathrm{~mL}$ of $50 \mathrm{~mm}$ tris-buffered saline $(\mathrm{pH}$ 7.0), and filtered using an acrodisc $13-\mathrm{mm}$ syringe filter with a $0.2-\mu \mathrm{m}$ nylon membrane (Fisher Scientific Company, Pittsburgh, PA) before being analyzed.

$t$-Zeatin riboside was extracted according to the procedure by Zhang and Ervin (2004) with some modifications. Leaf samples $(350 \mathrm{mg})$ were used for extraction. The $t$-ZR samples were dissolved in methanol $(30 \mu \mathrm{L})$ and diluted with $0.6 \mathrm{~mL}$ of $50 \mathrm{~mm}$ phosphate-buffered saline $(\mathrm{pH} 7.0)$ and filtered with an acrodisc $13-\mathrm{mm}$ syringe filter with $0.2-\mu \mathrm{m}$ nylon membrane before being analyzed (Man et al., 2011).

The ABA and $t$-ZR were analyzed using the SCL-10A VP HPLC system (Shimadzu, Japan) according to the methods described by Man et al. (2011). Briefly, an aliquot $(10 \mu \mathrm{L})$ of the filtered samples was injected into a Shim-Park C18 VP-ODS chromatographic column $(150 \mathrm{~mm} \times 4.6 \mathrm{~mm}, 5 \mu \mathrm{m})$ with isocratic elution at a flow rate of $0.7 \mathrm{~mL}$ $\min ^{-1}$ at $30{ }^{\circ} \mathrm{C}$ using methanol and $0.075 \%$ acetic acid as a mobile phase $(45: 55, \mathrm{v} / \mathrm{v})$. Detection of ABA and $t$-ZR was carried out at $254 \mathrm{~nm}$ by a Shimadzu SPD-10A VP ultraviolet detector and cochromatography with authentic standards (Sigma). Identification of the compounds was carried out by comparison of retention times and characteristic 
absorbance of the eluting peaks with authentic standard compounds.

Leaf $\mathrm{H}_{2} \mathrm{O}_{2}$ content. The $\mathrm{H}_{2} \mathrm{O}_{2}$ content was determined using the methods of Bernt and Bergmeyer (1974). Leaf sample (200 mg) was homogenized in $3 \mathrm{~mL}$ of $100 \mathrm{~mm}$ sodium phosphate buffer ( $\mathrm{pH}$ 6.8) and the extracts were centrifuged at $16,000 g_{n}$ for $5 \mathrm{~min}$ at $4{ }^{\circ} \mathrm{C}$. Then $0.17 \mathrm{~mL}$ of supernatant was added to $0.83 \mathrm{~mL}$ peroxidase reagent containing $83 \mathrm{~mm}$ sodium phosphate $(\mathrm{pH}$ 7.0), $0.005 \%$ (w/v) $o$-dianisiden, and $40 \mu \mathrm{g}$ peroxidase per $\mathrm{mL}$. The mixture was incubated at $30{ }^{\circ} \mathrm{C}$ for $10 \mathrm{~min}$, and $0.17 \mathrm{~mL}$ of $1 \mathrm{~m}$ perchloric acid was added to stop the reaction. The absorbance at $436 \mathrm{~nm}$ was read against a blank.

Leaf antioxidant enzyme activity. Frozen leaf tissues $(250 \mathrm{mg})$ were ground to a powder with a mortar and a pestle in liquid nitrogen, and then the powder was homogenized with $4 \mathrm{~mL}$ cold extraction buffer [50 mm Na $\mathrm{HPO}_{4} / \mathrm{NaH}_{2} \mathrm{PO}_{4}, \mathrm{pH}$ 7, $0.2 \mathrm{~mm}$ ethylenediamine-tetracetic acid (EDTA), and $1 \%$ polyvinylpyrrolidone (PVP)]. The extracts were centrifuged at $12,000 g_{n}$ for $20 \mathrm{~min}$ at $4{ }^{\circ} \mathrm{C}$. The supernatant was collected and stored in different tubes and used for the assay of enzyme activity (Zhang and Kirkham, 1996).

The activity of SOD was measured according to the method of Giannopolitis and Ries (1977) with modifications. A $3 \mathrm{~mL}$ reaction mixture was composed of $50 \mathrm{~mm}$ phosphate buffer ( $\mathrm{pH}$ 7.8), $1.3 \mu \mathrm{M}$ Riboflavin, $13 \mathrm{~mm}$ methionine, $0.1 \mathrm{~mm}$ EDTA, $63 \mu \mathrm{m}$ nitro blue tetrazolium (NBT), and $0.1 \mathrm{~mL}$ enzyme extract. The test tubes containing the mixture were placed under light at 3,000 lx for $10 \mathrm{~min}$, and absorbance at $560 \mathrm{~nm}$ was recorded. No purple color should appear in tubes without enzyme and NBT (CK 0). Tubes containing NBT but without enzyme should turn dark purple as the control (CK Max). One unit of SOD activity was defined as the amount of enzyme inhibited $50 \%$ photochemical reduction of NBT.

The CAT activity was determined through the decomposition of hydrogen peroxide $\left(\mathrm{H}_{2} \mathrm{O}_{2}\right)$, which was measured by a decrease in absorbance at $240 \mathrm{~nm}\left(\epsilon=39.4 \mathrm{M}^{-1} \mathrm{~cm}^{-1}\right)$ for $1 \mathrm{~min}$ (Chance and Maehly, 1955). The reaction mixture consisted of $50 \mathrm{~mm}$ phosphate buffer ( $\mathrm{pH} 7.0), 15 \mathrm{mM}_{2} \mathrm{O}_{2}$, and $0.1 \mathrm{~mL}$ enzyme extract. The reaction was started with enzyme extract.

The POD activity was measured as an increase in absorbance at $470 \mathrm{~nm}(\epsilon=26.6$ $\mathrm{mM}^{-1} \mathrm{~cm}^{-1}$ ) for $1 \mathrm{~min}$ following the oxidation of guaiacol (Rao et al., 1996). The reaction mixture contained $50 \mu \mathrm{L}$ of $20 \mathrm{~mm}$ guaiacol, $2.83 \mathrm{~mL}$ of $10 \mathrm{~mm}$ phosphate buffer $(\mathrm{pH} 7.0)$, $20 \mu \mathrm{L}$ of $40 \mathrm{~mm} \mathrm{H}_{2} \mathrm{O}_{2}$, and $0.1 \mathrm{~mL}$ enzyme extract. The reaction was started with the addition of $\mathrm{H}_{2} \mathrm{O}_{2}$.

APX activity was determined by following the decrease in absorbance at $290 \mathrm{~nm}$ because of ascorbic acid oxidation $(\epsilon=2.8$ $\mathrm{mm}^{-1} \mathrm{~cm}^{-1}$ ) according to Nakano and Asada (1981) as described by Zhang and Kirkham (1996). The $1.5 \mathrm{~mL}$ reaction mixture
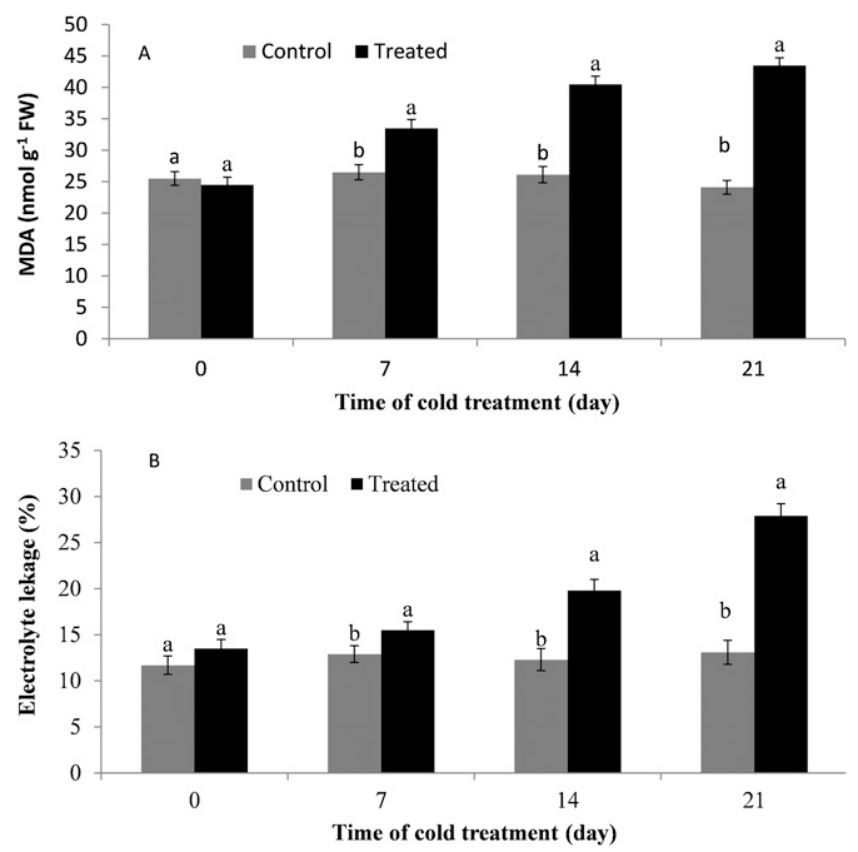

Fig. 1. Leaf electrolyte leakage (EL; mean $\pm \mathrm{SE}, \mathrm{n}=10$ ) and malondialdehyde (MDA content) responses to cold acclimation treatment in 'Chinese Common' zoysiagrass. The treatments marked with same letters are not significantly different at the given sampling date at $P=0.05$.
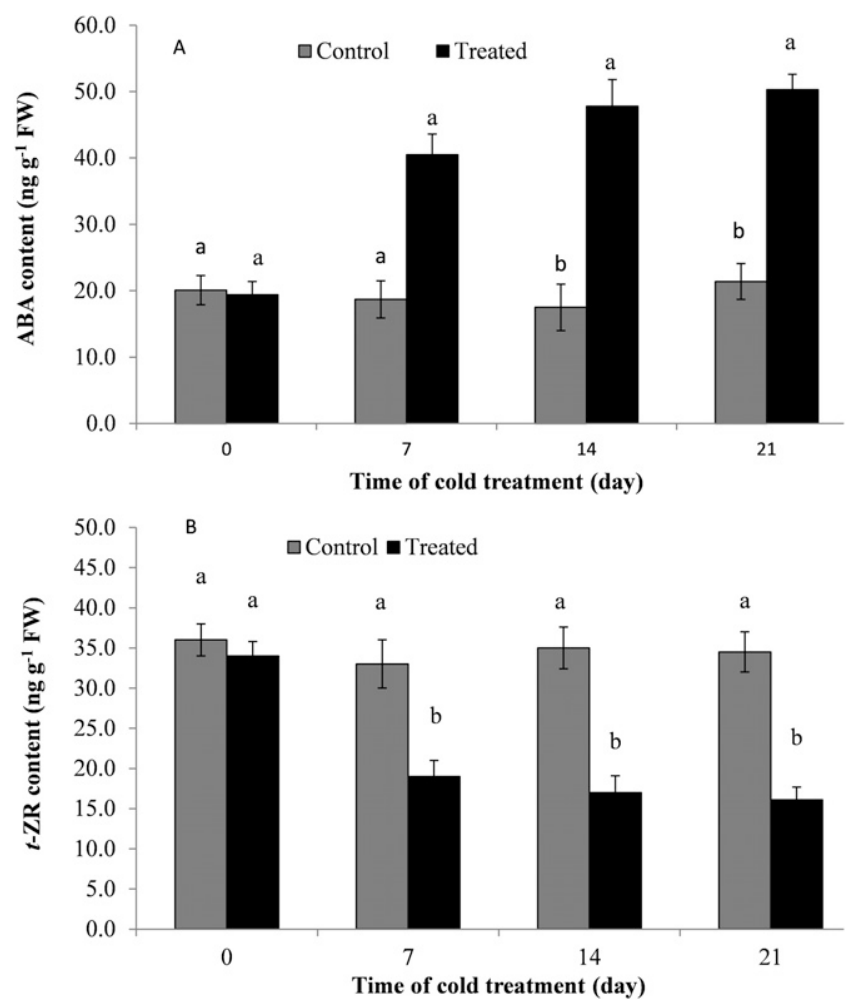

Fig. 2. (A) Leaf abscisic acid (ABA) and (B) transzeatin riboside $(t-Z R)$ content (mean $\pm \mathrm{SE}, \mathrm{n}=10$ ) responses to cold acclimation treatment in 'Chinese Common' zoysiagrass. The treatments marked with same letters are not significantly different at the given sampling date at $P=0.05$.

consisted of $0.5 \mathrm{~mm}$ ascorbic acid, $0.1 \mathrm{~mm}$ $\mathrm{H}_{2} \mathrm{O}_{2}, 0.1$ mm EDTA, 50 mm sodium phosphate buffer ( $\mathrm{pH} 7.00)$, and $50 \mu \mathrm{L}$ enzyme extract. The reaction was initiated by adding $\mathrm{H}_{2} \mathrm{O}_{2}$.

Leaf proline content. Leaf proline content was measured according to Bates et al.
(1973). Briefly, frozen leaf tissues $(50 \mathrm{mg}$ ) were crushed with liquid nitrogen and extracted with a pestle in an ice-cold mortar with $1 \mathrm{~mL}$ of $3 \% 5$-sulfosalicylic acid solution and the homogenate was transferred into $1.5 \mathrm{~mL}$ micro centrifuge tube. The tubes were vortexed for $15 \mathrm{~s}$ (four times), and 


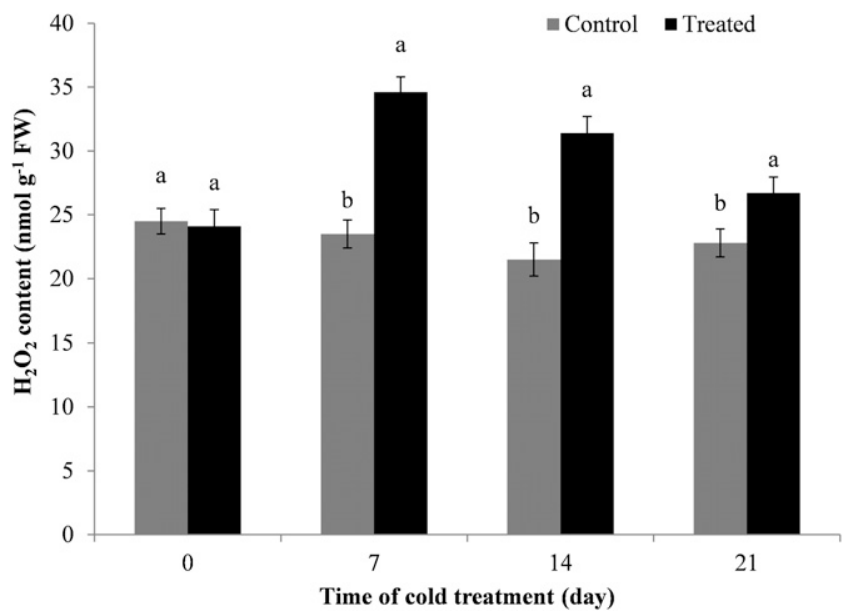

Fig. 3. Leaf hydrogen peroxide content (mean $\pm \mathrm{SE}, \mathrm{n}=10$ ) responses to cold acclimation treatment in 'Chinese Common' zoysiagrass. The treatments marked with same letters are not significantly different at the given sampling date at $P=0.05$.
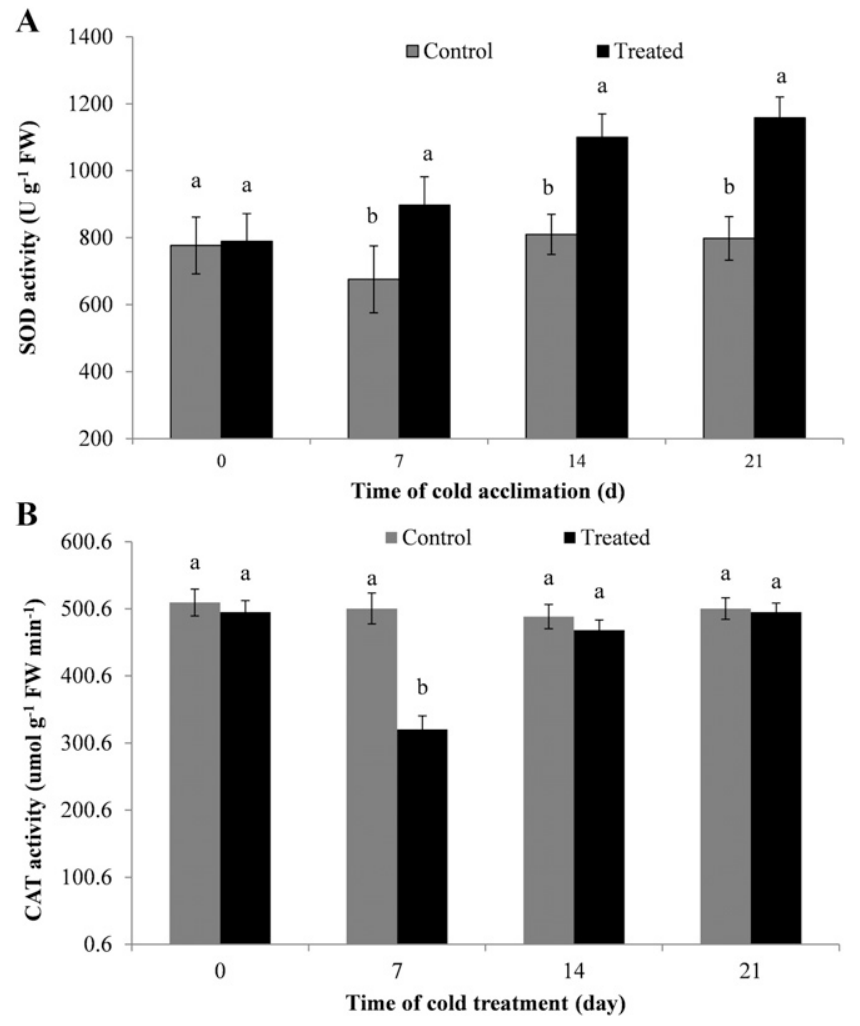

Fig. 4. (A) Leaf superoxide dismutase (SOD) and (B) catalase (CAT) activity (mean $\pm \mathrm{SE}, \mathrm{n}=10$ ) responses to cold acclimation treatment in 'Chinese Common' zoysiagrass. The treatments marked with same letters are not significantly different at the given sampling date at $P=0.05$.

then centrifuged at $16,000 g_{n}$ for $15 \mathrm{~min}$. Supernatant $(100 \mu \mathrm{L})$ was collected for proline assay. The aliquots were mixed with $900 \mu \mathrm{L}$ deionized water, $0.1 \mathrm{~mL}$ acid ninhydrin, and $1.0 \mathrm{~mL}$ glacial acetic acid. The tubes were vortexed for $15 \mathrm{~s}$ and then incubated in an oven at $100{ }^{\circ} \mathrm{C}$ for $1 \mathrm{~h}$, and cooled down in an ice bath. Toluene $(4.0 \mathrm{~mL})$ was added to each tube. After the tubes were vortexed for $20 \mathrm{~s}$ and allowed to stand for $5 \mathrm{~min}, 3.0 \mathrm{~mL}$ of the upper chromophore was transferred into test tubes and the absorbance was read at $520 \mathrm{~nm}$ in a spectrophotometer
(Spectrometer 2802s ultraviolet/VIS; Shanghai Precision and Scientific Inc.).

Experimental design and statistical analysis. A randomized complete block design was used with five replications. The data from the first and second experiment were analyzed using an ANOVA with two factors (experiment and cold treatment; SAS version 9.1.3) for each sampling date. Since there was no interaction between experiment and cold treatment, the data were reported as means of two experiments $(n=10)$. The mean separations were performed using a Fisher's protected LSD test at 5\% probability level.

\section{Results}

Leaf EL and MDA content. Cold treatment caused an increase in MDA content at 7, 14, and $21 \mathrm{~d}$ (Fig. 1A). At $21 \mathrm{~d}$, cold treatment increased MDA by $80 \%$ when compared with the control.

Cold treatment increased EL as observed at 7,14 , and $21 \mathrm{~d}$ of treatment (Fig. 1B). EL gradually increased in response to cold treatment. At $21 \mathrm{~d}$, cold treatment increased EL by $113 \%$ relative to the control.

Leaf $A B A$ and $t-Z R$ content. Cold treatment increased ABA content as measured at 7, 14, and $21 \mathrm{~d}$ (Fig. 2A). The greatest increase in $\mathrm{ABA}$ content occurred from 0 to $7 \mathrm{~d}$. The ABA level in the cold treated grass was similar at 14 and $21 \mathrm{~d}$. At $21 \mathrm{~d}$, cold treatment increased ABA content by $135 \%$ relative to the control.

Cold treatment reduced $t$-ZR content as measured at 7, 14, and $21 \mathrm{~d}$ (Fig. 2B). The $t$-ZR level dropped sharply from 0 to $7 \mathrm{~d}$ and then remained unchanged. At $21 \mathrm{~d}$, the $t$-ZR content in cold treated grass was only $58 \%$ of the control.

Leaf $\mathrm{H}_{2} \mathrm{O}_{2}$ content. $\mathrm{H}_{2} \mathrm{O}_{2}$ content increased sharply from 0 to $7 \mathrm{~d}$ and then declined from 7 to $21 \mathrm{~d}$ in response to cold treatment (Fig. 3). At $7 \mathrm{~d}$, cold treatment increased $\mathrm{H}_{2} \mathrm{O}_{2}$ content by $47 \%$ relative to the control. A higher $\mathrm{H}_{2} \mathrm{O}_{2}$ level in coldtreated grass was found at 7,14 , and $21 \mathrm{~d}$ when compared with the control.

Leaf antioxidant enzyme activity. Leaf SOD activity gradually increased from 0 to $21 \mathrm{~d}$ due to cold treatment (Fig. 4A). A higher SOD activity in the cold-treated grass was found at 7,14 , and $21 \mathrm{~d}$ relative to the control. At $21 \mathrm{~d}$, cold treatment increased SOD activity by $45 \%$ when compared with the control.

Cold treatment reduced CAT activity by $36 \%$ at $7 \mathrm{~d}$ of treatment (Fig. 4B). No difference in CAT activity was found between the treatment at 0,14 , and $21 \mathrm{~d}$.

APX activity declined at $7 \mathrm{~d}$ and increased at $14 \mathrm{~d}$ due to cold treatment (Fig. 5A). At $14 \mathrm{~d}$, cold treatment increased APX activity by $31 \%$ relative to the control. No difference in APX activity was found between the treatments at the end of cold treatment (21 d). POD activity dropped sharply from 0 to $7 \mathrm{~d}$ and then remained unchanged due to the cold treatment (Fig. 5B). At $21 \mathrm{~d}$, cold treatment reduced POD activity by $21 \%$.

Leaf proline content. Proline content increased gradually in response to cold treatment (Fig. 6). Higher proline content in the cold-treated grass relative to the control was observed at 14 and $21 \mathrm{~d}$. At $21 \mathrm{~d}$, cold treatment increased proline content by 3.1 fold relative to the control.

Stolon $L T_{50} \cdot \mathrm{LT}_{50}$ is a good indicator of freezing tolerance. Before cold treatment, the averaged $\mathrm{LT}_{50}$ was $-4.8{ }^{\circ} \mathrm{C}$. After $21 \mathrm{~d}$ of cold acclimation treatment, $\mathrm{LT}_{50}$ decreased from -4.8 to $-12.5^{\circ} \mathrm{C}$ (Fig. 7). 

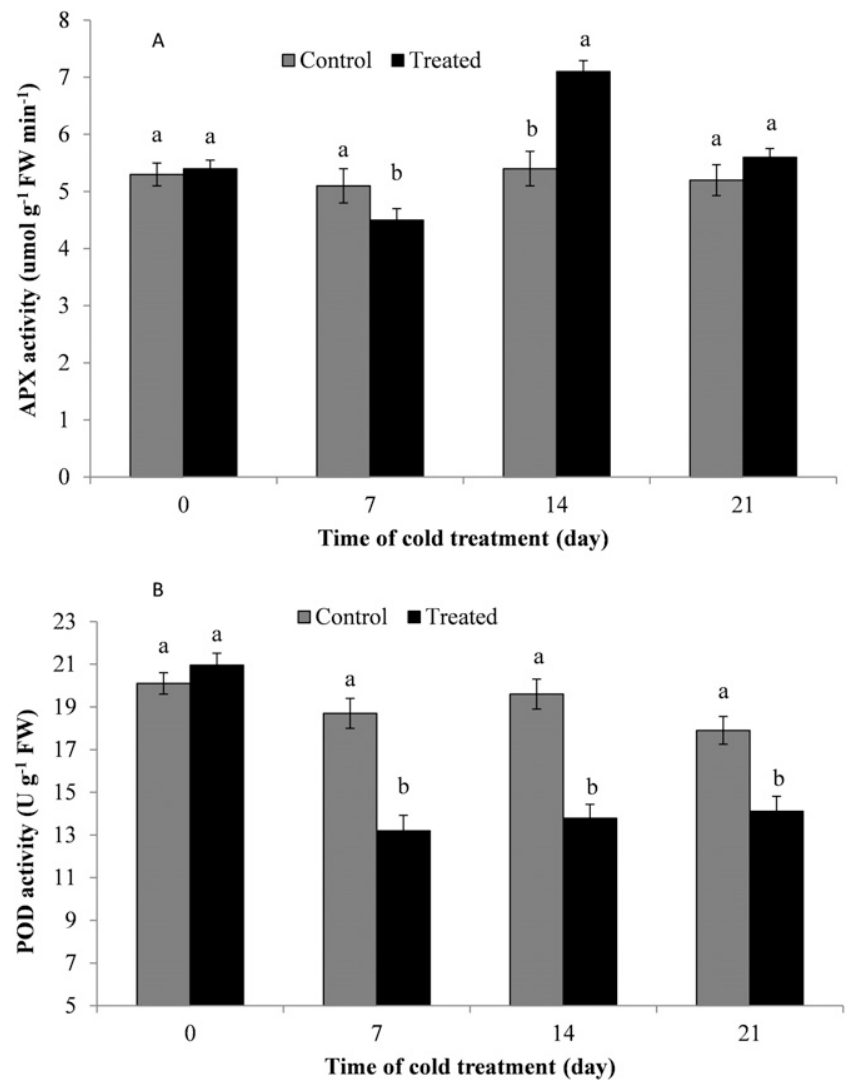

Fig. 5. (A) Leaf ascorbate peroxidase (APX) and (B) peroxidase (POD) activity (mean $\pm \mathrm{SE}, \mathrm{n}=10$ ) responses to cold acclimation treatment in 'Chinese Common' zoysiagrass. The treatments marked with same letters are not significantly different at the given sampling date at $P=0.05$.

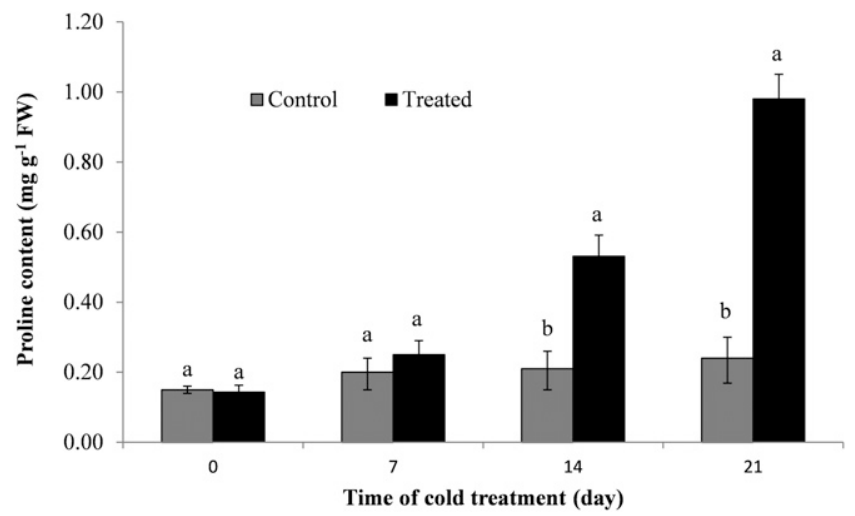

Fig. 6. Leaf proline (mean $\pm \mathrm{SE}, \mathrm{n}=10$ ) responses to cold acclimation treatment in 'Chinese Common' zoysiagrass. The treatments marked with same letters are not significantly different at the given sampling date at $P=0.05$.

\section{Discussion}

The results of this study indicated that the cold acclimation treatment resulted in an increase in ABA and decline in $t$-ZR content in zoysiagrass. The greatest change occurred during the first week of cold treatment. This is consistent with previous studies with warm-season turfgrass species (Zhang et al., 2009, 2011). Zhang et al. (2009) indicated that stolon ABA content in zoysiagrass increased from late fall to winter in the field conditions in Kansas state. Zhang et al. (2011) noted that cold acclimation treatment increased stolon ABA content and reduced cytokinin content in bermudagrass. Plants may close stomata in responses to abiotic stresses such as cold (Zhang and Ervin, 2008). ABA and cytokinin can regulate stomatal opening and closure, and higher ABA may induce stomatal closure (Davies, 2010). Closure of stomata would inhibit gas exchange and may cause oxidative stress and accumulation of ROS such as $\mathrm{H}_{2} \mathrm{O}_{2}$. The results of our study indicated that $\mathrm{H}_{2} \mathrm{O}_{2}$ increased sharply during first week of cold treatment. In addition, EL and MDA content increased in response to cold treatment. $\mathrm{Lu}$ et al. (2009) noted that $\mathrm{H}_{2} \mathrm{O}_{2}$ is involved in ABA-induced stomatal closure and enhanced activities of antioxidant enzymes in plants subjected to drought stress. This suggests that $\mathrm{H}_{2} \mathrm{O}_{2}$ and $\mathrm{ABA}$ may be involved in inducing defensive response during early stage of cold acclimation. Excess ROS may cause cell membrane lipid peroxidation (higher EL and MDA content). The results of our study suggest that cold acclimation may induce upregulation of $\mathrm{ABA}$ and $\mathrm{H}_{2} \mathrm{O}_{2}$ and mild cell membrane injury.

Increases in $\mathrm{ABA}$ and $\mathrm{H}_{2} \mathrm{O}_{2}$ may trigger plant defense systems such as certain antioxidant enzymes. It has been documented that $\mathrm{ABA}$ and $\mathrm{H}_{2} \mathrm{O}_{2}$ may serve as signal molecules in initiating plant defense systems during cold acclimation (Xiong et al., 2002). The results of this study indicated that cold acclimation increased antioxidant enzyme SOD and APX activity. SOD activity was higher in cold-treated grass relative to the control at 7,14 , and $21 \mathrm{~d}$. This is consistent with previous studies (Zhang et al., 2006; Zhang and Ervin, 2008). Higher SOD activity may effectively scavenge $\mathrm{O}_{2}$ and convert it to $\mathrm{H}_{2} \mathrm{O}_{2}$, which can further be converted to $\mathrm{H}_{2} \mathrm{O}$ and $\mathrm{O}_{2}$ by CAT and APX. The decrease of CAT activity at $7 \mathrm{~d}$ may be due to $\mathrm{H}_{2} \mathrm{O}_{2}$ depletion. Cold acclimation treatment may cause excess ROS production, which is related to the decline of certain enzyme activity from 0 through $7 \mathrm{~d}$. The increase in ROS level may trigger upregulation of SOD and APX activity as observed from $\mathrm{d} 7$ to $\mathrm{d} 14$. The SOD and other antioxidant enzymes and metabolites may suppress ROS and protect cells under lowtemperature stress (Zhang and Ervin, 2008).

The results of this study also showed that the leaf proline content increased in response to cold acclimation treatment. This supports previous studies by Patton et al. (2007a) who reported a significant increase in proline content during cold acclimation in zoysiagrass. Several researchers also found that proline content increased during cold acclimation in other warm-season turfgrasses (Cai et al., 2004; Munshaw et al., 2006; Zhang et al., 2006, 2008). Proline functions as an osmoprotectant and regulates cell $\psi_{\mathrm{S}}$ and stabilizes cell membrane during abiotic stresses. Proline also functions as an antioxidant to suppress ROS. The higher proline content in cells may alleviate dehydration and protect cells during freezing stress.

Cold acclimation treatment increased zoysiagrass freezing tolerance as $\mathrm{LT}_{50} \mathrm{de}$ creased from -4.8 to $-12.5^{\circ} \mathrm{C}$. Zhang et al. (2009) also found that $\mathrm{LT}_{50}$ of zoysiagrass decreased from late fall to winter in field conditions. Increases in ABA, antioxidant enzymes (SOD, APX), and proline because of cold acclimation treatment may contribute to the improvement of freezing tolerance. The cold-induced mild oxidative stress may increase ROS, which initiates antioxidant defense systems. 


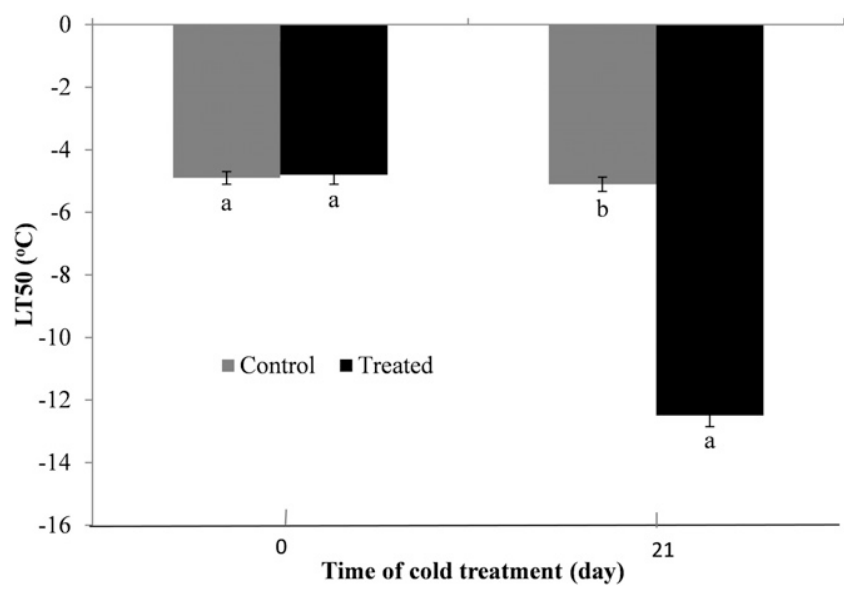

Fig. 7. Lethal temperature for $50 \%$ loss of electrolytes in stolons $\left(\mathrm{LT}_{50} ;\right.$ mean $\left.\pm \mathrm{SE}, \mathrm{n}=10\right)$ responses to cold acclimation treatment in 'Chinese Common' zoysiagrass. The treatments marked with same letters are not significantly different at the given sampling date at $P=0.05$.

\section{Conclusions}

The results of this study indicated that cold acclimation treatment induced an increase in ABA, $\mathrm{H}_{2} \mathrm{O}_{2}$, antioxidant enzyme (SOD and APX) activity, as well as in proline. ABA and $\mathrm{H}_{2} \mathrm{O}_{2}$ are involved in regulating plant antioxidant defenses. Cold treatment-induced upregulation of ABA, antioxidant enzyme (SOD and APX) activity, and proline may be closely associated with improvement of freezing tolerance (lower $\mathrm{LT}_{50}$ ). The results suggest that the hormone (ABA), antioxidant enzymes (SOD and APX), and osmopotectant (proline) are involved in cold acclimation process and associated with freezing tolerance and winter survival of zoysiagrass.

\section{Literature Cited}

Anderson, J.A., C.M. Taliaferro, and D.L. Martin. 2003. Longer exposure durations increase freeze damage to bermudagrasses. Crop Sci. 43:973-977.

Bates, L.S., R.P. Waldren, and I.D. Teare. 1973. Rapid determination of free proline for waterstress studies. Plant Soil 39:205-207.

Bernt, E. and H.U. Bergmeyer. 1974. Inorganic peroxides, p. 2246-2248. In: H.U. Bergmeyer (ed.). Methods of enzymatic analysis. Academic Press, New York, NY.

Blum, A. and A. Ebercon. 1981. Cell membrane stability as a measure of drought and heat tolerance in wheat. Crop Sci. 21:43-47.

Cai, Q., S. Wang, Z. Cui, J. Sun, and Y. Ishii. 2004. Changes in freezing tolerance and its relationship with the contents of carbohydrates and proline in overwintering centipedegrass (Eremochloa ophiuroides (Munro) Hack.). Plant Prod. Sci. 7:421-426.

Chance, B. and A.C. Maehly. 1955. Assay of catalases and peroxidases. Methods Enzymol. 2:764-775.

Davies, P.J. 2010. Plant hormones: Biosynthesis, signal transduction, and action. 3rd ed. Springer, New York, NY.

Dhindsa, R.S. and W. Matowe. 1981. Drought tolerance in two mosses: Correlated with enzymatic defense against lipid peroxidation. J. Expt. Bot. 32:79-91.

Fry, J.D. and B. Huang. 2004. Applied turfgrass science and physiology. John Wiley \& Sons, Hoboken, NJ.
Giannopolitis, C.N. and S.K. Ries. 1977. Superoxide dismutase. I. occurrence in higher plants. Plant Physiol. 59:309-314.

Gupta, A.S., J.L. Heinen, A.S. Holaday, J.J. Burke, and R.D. Allen. 1993. Increased resistance to oxidative stress in transgenic plants that overexpress chloroplastic $\mathrm{Cu} / \mathrm{Zn}$ superoxide dismutase. Proc. Natl. Acad. Sci. USA 90:1629-1633.

Heino, P., G. Sandman, V. Lång, K. Nordin, and E. T. Palva. 1990. Abscisic acid deficiency prevents development of freezing tolerance in Arabidopsis thaliana (L.). Heynh. Theor. Appl. Genet. 79:801-806.

Hsu, Y.T. and C.H. Kao. 2010. Abscisic acidinduced leaf senescence of rice seedlings is due to hydrogen peroxide accumulation. Crop Environ. Bioinform. 7:243-249.

Hu, X., A. Zhang, J. Zhang, and M. Jiang. 2006. Abscisic acid is a key inducer of hydrogen peroxide production in leaves of maize plants exposed to water stress. Plant Cell Physiol. 47:1484-1495.

Karpinski, S., G. Wingsle, B. Karpinska, and J. Hallgren. 2002. Low temperature stress and antioxidant defense mechanisms in higher plants, p. 69-103. In: D. Inze and M. Van Montagu (eds.). Oxidative stress in plants. Taylor \& Francis, London, UK.

Lu, S., W. Su, H. Li, and Z. Guo. 2009. Abscisic acid improves drought tolerance of triploid bermudagrass and involves $\mathrm{H}_{2} \mathrm{O}_{2}$ - and NOinduced antioxidant enzyme activities. Plant Physiol. Biochem. 47:132-138.

Man, D., Y.X. Bao, L.B. Han, and X. Zhang. 2011. Drought tolerance associated with proline and hormone metabolism in two tall fescue culti-

McKersie, B.D. and S.R. Bowley. 1997. Active oxygen and freezing tolerance in transgenic plants, p. 203-214. In: P.H. Li and T.H.H. Chen (eds.) Plant cold hardiness. Plenum Press, New York, NY

Munshaw, G.C., E.H. Ervin, C. Shang, S.D. Askew, X. Zhang, and R.W. Lemus. 2006. Influence of late-season iron, nitrogen, and seaweed extract on fall color retention and cold tolerance of four bermudagrass cultivars. Crop Sci. 46:273-283.

Nakano, Y. and K. Asada. 1981. Hydrogen peroxide is scavenged by ascorbate-specific peroxidase in spinach chloroplasts. Plant Cell Physiol. 22:867-880. vars. HortScience 46:1027-1032.
Patton, A.J., S.M. Cunningham, J.J. Volenec, and Z. J. Reicher. 2007a. Differences in freeze tolerance of zoysiagrasses: I. Role of proteins. Crop Sci. 47:2162-2169.

Patton, A.J., S.M. Cunningham, J.J. Volenec, and Z.J. Reicher. 2007b. Differences in freeze tolerance of zoysiagrasses: II. Carbohydrate and proline accumulation. Crop Sci. 47:21702181.

Patton, A.J. and Z.J. Reicher. 2007. Zoysiagrass species and genotypes differ in their winter injury and freeze tolerance. Crop Sci. 47:16191627.

Perl-Treves, R. and A. Perl. 2002. Oxidative stress: An introduction, p. 1-32. In: D. Inze and M. Van Montagu (eds.). Oxidative stress in plants. Taylor \& Francis, London, UK.

Prasad, T.K., M.D. Anderson, and C.R. Stewart. 1994. Acclimation, hydrogen peroxide, and abscisic acid protect mitochondria against irreversible chilling injury in maize seedlings. Plant Physiol. 105:619-627.

Rao, M.V., G. Paliyathm, and D.P. Ormond. 1996. Ultraviolet-B and ozone induced biochemical changes in antioxidant enzymes in Arabidopsis thaliana. Plant Physiol. 110:125-136.

Rogers, R.A., J.H. Dunn, and C.J. Nelson. 1977. Photosynthesis and cold hardening in zoysia and bermudagrass. Crop Sci. 17:727-732.

SAS Institute, Inc. 2004. SAS v.9.1.3. SAS Institute, Inc. Cary, NC.

Systat Software. 2007. Sigmaplot v.10. San Jose, CA.

Thomashow, M.F. 1999. Plant cold acclimation: Freezing tolerance genes and regulatory mechanisms. Annu. Rev. Plant Physiol. Plant Mol. Biol. 50:571-599.

Taylor, J.S., M.K. Bhalla, J.M. Robertson, and L.J. Piening. 1990. Cytokinins and abscisic acid in hardening winter wheat. Can. J. Bot. 68:15971601.

Xiong, L., K.S. Schumaker, and J.K. Zhu. 2002. Cell signaling during cold, drought, and salt stress. Plant Cell 14:S165-S183.

Zhang, Q., J. Fry, X. Pan, C. Rajashekar, D. Bremer, M. Engelke, and X. Wang. 2009. Cold acclimation of Zoysia japonica and Z. matrella and changes in rhizome abscisic acid levels. Intl. Turfgrass Soc. Res. J. 11:883-889.

Zhang, X. and E.H. Ervin. 2004. Cytokinincontaining seaweed and humic acid extracts associated with creeping bentgrass leaf cytokinins and drought resistance. Crop Sci. 44:1737-1745.

Zhang, X. and E.H. Ervin. 2008. Metabolic defense responses of bermudagrass during acclimation to freezing stress: A review. Acta Hort. 783:181-194.

Zhang, X., E.H. Ervin, and A.J. LaBranche. 2006. Metabolic defense responses of seeded bermudagrass during acclimation to freezing stress. Crop Sci. 46:2598-2605.

Zhang, X., E.H. Ervin, C. Waltz, and T. Murphy. 2011. Metabolic changes during cold acclimation and deacclimation in five bermudagrass varieties: II. Cytokinin and abscisic acid metabolism. Crop Sci. 51:847-853.

Zhang, X., K. Wang, and E.H. Ervin. 2008. Bermudagrass freezing tolerance associated with abscisic acid metabolism and dehydrin expression during cold acclimation. J. Amer. Soc. Hort. Sci. 133:542-550.

Zhang, J. and M.B. Kirkham. 1996. Enzymatic responses of the ascorbate-glutathione cycle to drought in sorghum and sunflower plants. Plant Sci. 113:139-147. 